\title{
Computer Speech-Based Remediation for Reading Disabilities: The Size of Spelling-to-Sound Unit in a Transparent Orthography
}

\author{
Juan E. Jiménez ${ }^{1}$, Isabel Hernández-Valle ${ }^{1}$, Gustavo Ramírez ${ }^{1}$, \\ $\mathrm{M}^{\mathrm{a}}$ del Rosario Ortiz ${ }^{1}$, Mercedes Rodrigo ${ }^{1}$, Adelina Estévez ${ }^{1}$, \\ Isabel O’Shanahan ${ }^{1}$, Eduardo García ${ }^{2}$, and María de la Luz Trabaue ${ }^{1}$ \\ ${ }^{1}$ Universidad de La Laguna and ${ }^{2}$ Free University Amsterdam
}

\begin{abstract}
This study was designed to assess the effects of four reading-training procedures for children with reading disabilities (RD) in a transparent orthography, with the aim of examining the effects of different spelling-to-sound units in computer speech-based reading. We selected a sample of 83 Spanish children aged between 7 years 1 month and 10 years 6 months $(\mathrm{M}=105.2$, SD $=7.8$ ) whose pseudoword reading performance was below the 25 th percentile and IQ $>90$. The participants were randomly assigned to five groups: (a) the whole-word training group (WW) $(\mathrm{n}=17),(\mathrm{b})$ the syllable training group $(\mathrm{S})(\mathrm{n}=16)$, (c) the onset-rime training group $(\mathrm{OR})(\mathrm{n}=17)$, (d) the phoneme training group $(\mathrm{P})(\mathrm{n}=15)$, and (e) the untrained control group (n $=18$ ). Children were pre- and post-tested in word recognition, reading comprehension, phonological awareness, and orthographic and phonological tasks. The results indicate that experimental groups who participated in the phoneme and syllable conditions improved their word recognition in comparison with the control group. In addition, dyslexics who participated in the phoneme, syllable, and onset-rime conditions made a greater number of requests during computer-based word reading under conditions that required extensive phonological computation (low frequency words and long words). Reading time, however, was greater for long words in the phoneme group during computer-based reading. These results suggest the importance of training phonological processes in improving word decoding in children with dyslexia who learn in a consistent orthography.

Keywords: computer-assisted reading, dyslexia, reading disabilities, speech feedback, remedial reading
\end{abstract}

Esta investigación fue diseñada para evaluar los efectos de la instrucción asistida a través de ordenador en los procesos fonológicos y de lectura en niños con dificultades de aprendizaje en la lectura (DAL) en una ortografía transparente. Para ello se manipularon diferentes tipos de unidades lingüísticas con objeto de analizar con cuál de ellas se consiguen mejores resultados. Se seleccionó una muestra de 83 niños españoles de edades comprendidas entre los 7 años y 1 mes y 10 años y 6 meses (edad $\mathrm{M}=105.2$; $\mathrm{DT}=7.8$ ) que presentaban una puntuación en lectura de pseudopalabras por debajo del percentil 25 y un cociente intelectual mayor que 90. Los sujetos fueron distribuidos al azar en cinco grupos diferentes: (a) instrucción basada en reconocimiento de palabras (WW) $(n=17)$, (b) instrucción basada en reconocimiento de sílabas $(S)(n=16)$, (c) instrucción basada en reconocimiento de principio-rima $(O R)(n=17)$, (d) instrucción basada en reconocimiento de fonemas $(P)(n=15)$, y (e) ningún tipo de instrucción $(n=18)$. Se administraron distintas tareas, antes y después de finalizado el periodo de instrucción, para evaluar los efectos de la instrucción sobre la descodificación, comprensión lectora, conciencia fonológica, y procesamiento ortográfico. Los niños con DAL que participaron en la instrucción basada en el reconocimiento de fonemas y en la instrucción basada en reconocimiento de sílabas mejoraron la descodificación en comparación al grupo control. Además, los niños con DAL que participaron en las condiciones de fonema, sílaba y principio-rima solicitaron un mayor número de ayudas durante el periodo de instrucción en aquellas condiciones donde la demanda de procesamiento fonológico era mayor ( $v$. gr., palabras de baja frecuencia y palabras largas). Sin embargo, se registraron tiempos de lectura mayores, durante el periodo de instrucción, para las palabras largas en la condición de entrenamiento basada en fonemas. Estos hallazgos sugieren que el entrenamiento en procesos fonológicos mejora la descodificación de las palabras en niños con DAL en una ortografía transparente.

Palabras clave: instrucción asistida a través de ordenador, dislexia, dificultades de aprendizaje de la lectura, ayuda correctiva, reeducación

This research was supported by a grant from DGICYT (Dirección General de Investigación Científica y Técnica, number PB940587, Ministerio de Educación y Ciencia).

Correspondence concerning this article should be addressed to Juan E. Jiménez, Departamento de Psicología Evolutiva y de la Educación, Universidad de La Laguna, Campus de Guajara, 38200 Islas Canarias, España. Phone 34-(9)22-317545 fax 34(9)22-317461. E-mail: ejimenez@ull.es 
Nowadays, there is consensus that many cases of reading disability are caused by difficulties in word decoding, suggesting that word identification problems are basically phonological route problems (e.g., Olson, Kliegl, Davidson, \& Foltz, 1985; Perfetti, 1985; Rack, Snowling, \& Olson, 1992; Siegel \& Ryan, 1988; Stanovich, 1988; Van den Bos \& Spelberg, 1994; Wagner \& Torgesen, 1987). Many studies carried out in languages with opaque orthography using the Reading Level (RL) match design have provided empirical evidence in favor of the deficit model in phonological processing, it being the case that dyslexics have more difficulty in reading nonwords than normal readers matched in age or in RL match design (Olson, Wise, Conners, Rack, \& Fulker, 1989; Stanovich \& Siegel, 1994). The degree of phonological reading deficit is not, furthermore, related to the degree of discrepancy between reading and IQ (for a review see, Stanovich \& Siegel, 1994). There is, however, some empirical evidence in a transparent orthography such as Spanish, demonstrating that the reading disabled do show severe difficulties in the use of the phonological route in the same way as they do in the English language (e.g., Domínguez \& Cuetos, 1992; Jiménez \& Hernández-Valle, 2000; Jiménez \& Ramírez, 2002; Rodrigo \& Jiménez, 1999), suggesting that a phonemic deficit is curtailing the development of phonological decoding (Jiménez, 1997; Jiménez, et al., 2005).

An increasing number of researchers have used computers in experiments on the remediation of reading disabilities (e.g., Jones, Torgesen \& Sexton, 1987; Olofsson, 1992; Olson \& Wise, 1992; Torgesen \& Barker, 1995; Van Daal \& Reitsma, 1993; Van der Leij, 1994). Recent developments in computer speech technology have made it possible to coordinate speech with written word presentation. The computer can also orthographically segment and "speak" the word at syllable and subsyllable levels and the simultaneous highlighting of the orthographic segment and the presentation of its corresponding speech sound provides a powerful means of emphasizing the relations between groups of letters and their sounds during reading. It has been demonstrated that reading on the computer with speech feedback significantly improves disabled readers' phonological decoding and word recognition (Olson, Foltz, \& Wise, 1986). For instance, Van Daal and Reitsma (1993) examined whether it is best to give feedback on all words or to allow the disabled readers to decide when they require such feedback. It was found that reading-age matched reading disabled children did not learn fewer words when the computer delivered the spoken form of all words even if this had not been requested. In addition, the results of a series of small quasi-experimental studies indicated positive treatment effects, in which the dyslexics who received computer training with speech feedback, improved their performance in reading and spelling, in comparison with students who only had access to conventional special education (Lundberg, 1995).
Studies of computer-aided remediation for reading disabled children have demonstrated, moreover, that word recognition skills improve when different forms of orthographic units are manipulated (Olson \& Wise, 1992). In the teaching of reading, print-to-sound translation can be trained using linguistic units of different sizes: a word can be taught as a whole unit, in individual letter-sound units, or in sublexical units of intermediate size (syllable, Basic Orthographic Syllabic Structure-BOSS-, onset-rime). However, the spelling-to-sound unit used in training may be a critical factor in determining the effectiveness of remedial instruction for RD. That said, it remains the case that the number of irregular words, monosyllabic and multisyllabic words, and the differences between the processing of words and pseudowords depend on the transparency of the orthography. Many differences exist among alphabetic writing systems with respect to the relationship between spelling and phonology. The notion of orthographic depth has been coined to characterize the degree of complexity of the mapping between orthographic and phonological representations (Liberman, Liberman, Mattingly, \& Shankweiler, 1980). Writing systems with more complex letter-phoneme relations are referred to as deeper orthographies (e.g., English) (Van den Bosch, Content, Daelemans, \& de Gelder, 1994). In this case, various remedial studies carried out in English have tried to determine the optimal size of the spelling-to-sound unit to be used in computer speech-based training of RD (e.g., Lovett, Barron, Forbes, Cuksts, \& Steinbach, 1994; Olson \& Wise, 1992; Wise et al., 1989). The results of these studies show differences for irregular words, regular words and pseudowords, multisyllabic and monosyllabic words. The word unit was effective for irregular word reading, whereas onset-rime and phoneme units were better than whole word for reading regular words (Lovett, et al., 1994). The word and onset-rime conditions were better for word reading, however, BOSS and onset-rime were superior in pseudoword reading (Wise et al., 1989). Wise et al. also showed that the onset-rime unit was less effective for multisyllabic words.

Spanish, on the other hand, is an example of shallow orthography in which the regularity in the letter-phoneme correspondences is high. In this language, irregular words do not exist, there are few monosyllabic words, with multisyllabic predominating words. Syllables are well defined, and pronunciation depends on the syllabic context (e.g., $c$ is pronounced $/ \mathrm{k} /$ when it is followed by the vowels $a, o$, and $u$, and $/ \Theta /$ when it is followed by the vowels $e$ and $i ; g$ is pronounced as $/ \mathrm{g} /$ when it is followed by the vowels $a, o$, and $u$, and $/ \mathrm{x} /$ when it is followed by the vowels $e$ and $i$; and $r$ is pronounced as $/ \wedge \mathrm{r} /$ whether it appears at the beginning of the word or when it is preceded by the letters $l, n$, and $s$, and $/ \overline{\mathrm{r}} /:$ rest). Moreover, the number of different syllabic structures is limited, and the irregularities can be resolved by taking into account the overall syllable where they appear. In Spanish, therefore, decoding does not represent a problem and for this reason, the most frequently recommended instructional method is phonics. 
The particularities of Spanish do, of course, have an influence on the processing of written words. For example, various studies carried out in Spanish with adults (Álvarez, de Vega, \& Carreiras, 1998; Carreiras, Álvarez, \& de Vega, 1993; Domínguez, Cuetos, \& de Vega, 1993) and children (Jiménez \& Guzmán, 2003) have demonstrated that syllables are computed during the processing of Spanish printed words, while the onset-rime units are not relevant in reading (Jiménez, Álvarez, Estévez, \& Hernández-Valle, 2000). Thus, as Spanish is a language with a high degree of orthographic consistency, it is expected that segmented-word units, such as phonemes and syllables, better than onset-rime units, may develop the grapheme-phoneme correspondence knowledge of RD children. Consequently, in the present study these units (i.e., phonemes, syllables, and onset-rime units) have been included in a remedial program to observe their differential effects after treatment.

The whole word is a unit that can also be included in a remedial instructional program for RD children. In Spanish, there is empirical evidence that the children use orthographic and phonemic cues in printed word recognition (Defior, Justicia, \& Martos, 1996; Domínguez \& Cuetos, 1992; Jiménez \& Hernández-Valle, 2000; Jiménez \& Rodrigo, 1994; Valle-Arroyo, 1989). In order to assess these reading strategies, psycholinguistic parameters such as familiarity, length, and syllabic structure have traditionally been used but neither regularity nor homophony effects can be studied with Spanish subjects, given the regular nature of grapheme phoneme correspondences. So, for instance, despite the regularity of the Spanish language, there is evidence that word frequency has an effect on reading time and it would imply the use of direct access, as the phonological route is widely taken to be prelexical (García-Albea, Sánchez, \& del Viso, 1982; Jiménez \& Hernández-Valle, 2000; Jiménez \& Rodrigo, 1994; Valle-Arroyo, 1989). In addition, empirical evidence in Spanish has been furnished in favor of the hypothesis that RD children have a bias for lexical over phonological procedures when reading, and that they use these as a compensatory strategy for their deficits in phonological decoding (Jiménez \& Hernández-Valle, 2000; Rodrigo \& Jiménez, 1999). It is our view that designers of remedial programs should take into account the fact that, in a regular language such as Spanish, RD children use the orthographic route for reading . The results of the studies of the effects of different spelling-to-sound units in computer speech-based reading cited above may suggest that characteristics of the language have an influence on the processing of reading and, that being the case, that the results obtained in orthographically non-transparent language cannot be generalized to transparent languages.

The present study, therefore, develops and evaluates four reading-training procedures with the aim of examining the effects of different spelling-to-sound units in computer speech-based reading for RD children who read a regular orthography. To this end, four reading-training conditions (i.e., whole-word, phoneme, syllable, and onset-rime,) were compared with an untrained control condition.

We hypothesized that the phoneme and syllable experimental training groups would show greater gains in word decoding than whole-word and onset-rime groups, in comparison with the control group. This reasoning is based on the evidence that in the phoneme and syllable conditions, readers have to combine the constituent phonemes and syllables to identify the word after simultaneously hearing and seeing the sound and the letters of the word, phonemeby-phoneme, or syllable-by-syllable. In these cases, the segmented feedback would facilitate the basic process of decoding graphemes into phonemes.

In contrast, when the whole-word is presented, the reader does not have to attend to the word's component elements, nor put them together in order to identify the word, because the whole-word sound has already been presented, thus no decoding abilities are required. The same may apply to the onset-rime condition in the Spanish language. In this case, a large portion of the word is also presented (e.g., c-urso [course]; tr-ato [relation]), being similar to the whole-word condition (e.g., curso; trato).

Our second prediction was that the differences in reading accuracy and requests for speech feedback as a function of the variables that allow us to test the routes-such as familiarity, syllabic structure, and word length — would be greater in the individuals with RD who are trained by phoneme and syllable conditions than in those who are trained by whole-word or onset-rime conditions across the treatment sessions. This means that they would be more affected by unfamiliar and longer words, and words with consonant-consonant-vowel (CCV) syllables. Thus, it was expected that phoneme and syllable groups would show longer reading times (RT) and a higher incidence of requests for speech feedback because of their greater phonological demands across treatment sessions. At the same time, greater reading accuracy was expected in these groups for the unfamiliar, longer words, and words with CCV syllables than the whole-word and onset-rime groups, thus reflecting the positive effects of the treatment.

\section{Method}

\section{Participants}

The initial sample was selected by soliciting teachers' opinions about which children had specific difficulties with reading, while having either no history of academic failure or difficulties with all subjects. Ultimately, however, we only studied the children with poor reading performance according to the results obtained from the administration of the PROLEC Pseudoword subtest (Cuetos, Rodríguez, \& Ruano, 1996). A sample of 83 Spanish children whose reading performance was below the $25^{\text {th }}$ percentile and IQ $>90$ were 
selected. The children came from urban zones and from average socio-economic backgrounds, and were attending several different state schools. Their age range was between 7 years 1 month and 10 years 6 months $(M=105.2, S D=$ 7.8). The participants were randomly assigned to the phoneme training group $(n=15 ; 12$ male, 3 female; age $M=107.5$, $S D=7.9)$, the whole-word training group $(n=17 ; 14$ male, 3 female; age $M=104.3, S D=8.5)$, the syllable training group ( $n=16 ; 8$ male, 8 female; age $M=105.6, S D=7.9$ ), the onset-rime training group ( $n=17 ; 6$ male, 11 female; age $M=104.5, S D=6.2)$, or the untrained control group ( $n$ = $18 ; 14$ male, 4 female; age $M=104.7, S D=9.1)$. There were no significant differences between groups in terms of age, $F(4,81)=.37, p=.82$. Test results also showed that there were no differences between groups in terms of IQ, $F(4,81)=.80, p=.52$, neither were differences in verbal working memory found, $F(4,81)=1.04, p=.38$. However, there were significant gender differences $\chi^{2}(4, N=83)=$ $13.2, p<.01$ These children had learned to read by phonic instruction, with grapheme-phoneme correspondences explicitly taught in first grade (at 6 years old). This method moves children gradually from simple to complex correspondences and is the most common approach to reading instruction in Spanish schools. Children who had sensory deficits, acquired neurological deficits, or other problems traditionally used as exclusionary criteria for learning disabilities were excluded. Table 1 contains means and standard deviations for the five groups on the IQ, age and working memory measures.

\section{Assessment Tests}

Culture Fair (or Free) Intelligence Test. A measure of “g." Scale I (Cattell \& Cattell, 1950/1989). This test includes eight subtests of which we only administered the short form: Substitution, Labyrinth, Identification and Similarities. The test allows us to obtain a measurement of the "g" factor.

Verbal Working Memory. To assess the children's working memory, we administered the task used by Siegel and Ryan (1989). In this task, which was modeled on the procedure developed by Daneman and Carpenter (1980), the children heard some sentences that had the final word missing. There were three trials at each level of set size (2, 3, 4, and 5 words). The task consisted of supplying the missing word and then repeating all the missing words from the set. For each level or set size, the score was 1 when the child performed the task successfully, and 0 score when he or she failed. Task administration was stopped when the child failed all the trials at one level.

Standardized Reading Skills Test PROLEC (Cuetos, et al., 1996). This Spanish standardized reading test includes various reading subtests. We only administered the following subtests that are included in the section Word-Pseudoword reading: (a) Lexical decision task (30 items); (b) Word reading (30 items); (c) Pseudoword reading (30 items); and (d) Word-Pseudoword reading (60 items). We also administered two Text Comprehension subtests. The Word and Pseudoword reading subtests require the correct identification of ordinary words and pseudowords with different linguistic structures: consonant-consonant-vowel (CCV), consonant-vowel-vowel (CVV), consonant-vowelconsonant (CVC), consonant-consonant-vowel-consonant (CCVC), consonant-vowel-vowel-consonant (CVVC), and vowel-consonant (VC). All subtests measure the accuracy of the responses. Accuracy was calculated taking the four subtests together and these scores were averaged. The comprehension subtests includes two short stories (64 and 62 words, respectively) and four questions each which were given to the children after reading. The measure was the total number of questions correctly answered. The authors reported an alpha coefficient of $\alpha=.92$, using as validity criteria the teacher's ratings of reading ability. Teachers were asked to rate reading ability on a 10- point scale, ranging from low ability (1) to high ability (10). All correlations between reading measures and teacher's ratings were significant statistically $(p<.001)$.

Phonological awareness tests. Three phonological awareness tasks were used to measure levels of intrasyllabic and phonemic awareness. By using these tasks, it has been demonstrated that Spanish reading-disabled children performed worse than average readers matched in age, and also children with reading disabilities performed more poorly than the younger normal readers in phoneme reversal and phoneme segmentation tasks (Jiménez, 1997).

Table 1

Means and Standard Deviations of IQ, Age, and Working Memory Measures

\begin{tabular}{|c|c|c|c|c|c|c|c|c|c|c|}
\hline \multicolumn{11}{|c|}{ Training Groups } \\
\hline & \multicolumn{2}{|c|}{$\begin{array}{l}\text { Control } \\
(n=18)\end{array}$} & \multicolumn{2}{|c|}{$\begin{array}{l}\text { Phoneme } \\
(n=15)\end{array}$} & \multicolumn{2}{|c|}{$\begin{array}{l}\text { Whole-Word } \\
\quad(n=17)\end{array}$} & \multicolumn{2}{|c|}{$\begin{array}{l}\text { Syllable } \\
(n=16)\end{array}$} & \multicolumn{2}{|c|}{$\begin{array}{l}\text { Onset-rime } \\
\quad(n=17)\end{array}$} \\
\hline & $M$ & $S D$ & $M$ & $S D$ & $M$ & $S D$ & $M$ & $S D$ & $M$ & $S D$ \\
\hline IQ & 108.4 & 17.0 & 113.6 & 15.5 & 105.8 & 12.7 & 109.9 & 19.5 & 114.1 & 16.9 \\
\hline Age & 104.7 & 9.1 & 107.5 & 7.9 & 104.3 & 8.5 & 105.6 & 7.9 & 104.5 & 6.2 \\
\hline Working Memory & 3.0 & 1.0 & 2.8 & 1.4 & 2.9 & 1.4 & 3.2 & 1.2 & 3.5 & 0.9 \\
\hline
\end{tabular}


The Odd-word-out task was based on that of Bowey and Francis (1991) but with pictures to test the awareness of intrasyllabic segments. The examiner presented a list of 4 pictures and asked the children the names of the pictures. In all stimuli, the initial target consonants were part of a CV unit. The instructions were: "I am going to show you some pictures. Look at these pictures. Tell me the names of the pictures. There is an /oveja/ (sheep), an /oso/ (bear), an /ojo/ (eye), and an /araña/ (spider). Now, we have to guess which pictures begin with a different sound. Here is an /oveja/, does it begin with /o/? Yes, it does. Now, here is an /oso/, does it begin with /o/? Yes, it does. Now, here is an /ojo/, does it begin with /o/? Yes, it does. Now, here is an /araña/, does it begin with /o/? No, it does not begin with /o/." The examiner did not provide any additional help in the task, and the child had to identify the picture that began with a different sound. This task had 3 examples and 10 items. Each item had four pictures. The children had to isolate the following phonemes on this task : $/ \mathrm{r} /, / \mathrm{l} /, / \mathrm{j} /, / \mathrm{m} /$, $/ \mathrm{t} /, / \mathrm{k} /$, and $/ \mathrm{p} /$. A complete list of stimuli for this and the following tasks appears in the Appendix 1.

In the Phoneme segmentation test, the children counted the phonemes of bisyllabic words with CVCV structure that were presented orally and used aids such as rods. In the examples, the examiner pronounced a word and tapped the phonemes. The instructions were: "Listen, <sapo> (toad). How many parts does it have? It has four parts, doesn't it? The parts are /s/-/a/-/p/-/o/. Do you understand the game? If you need some help you can use these rods." The examiner did not help the children any further. Each word was presented individually and the examiner asked the children how many parts the word had. This task had 2 examples and 14 items.

Finally, in the Phoneme reversal test, the children counted the phonemes of bisyllabic words with CVCV structure by reversing the order of segments in each word. In the examples, the examiner pronounced a word and the instructions were: "Listen, <misa> (mass). How many parts does it have? It has four parts, doesn't it? The parts are /a//s/-/i/-/m/ Do you understand the game?" The examiner did not provide any further help to the children. Each word was presented individually and the examiner asked the children how many parts the word had. This task had 2 examples and 14 items.

For all subtests, the score was 1 when the child performed the item successfully, and 0 when he or she failed.

Accuracy was calculated taking the three subtests together, and these scores were averaged. For another study (Jiménez, 1997), a reliability analysis on the different phonological awareness tasks was conducted and the alpha coefficient calculated on a heterogeneous sample of children age range similar to this study. The alpha coefficient for the odd-word-out task was $\alpha=.70$. In the case of phoneme segmentation task, it was $\alpha=.98$, and in the phoneme reversal, $\alpha=.98$
Phonological word decoding task. This task was also adapted from one designed by Siegel (1992). In this task, there were 32 trials in which two stimuli were presented for each trial. The child was required to specify which of two visually presented pseudowords (e.g., kiero-ciero, dotordoktor) sounded like a real word. A reliability analysis was used and the alpha coefficient was $\alpha=.77$.

Orthographic word decoding task. This task was adapted from one designed by Siegel (1992). We used accuracy measures because there is empirical evidence in Spanish that this measure is sensitive to individual differences in reading (Rodrigo et al., 2004).

In this task, there were 32 trials in which two stimuli were presented for each trial. The child was presented with a real word and pseudoword (e.g., sonrisa-sonrrisa, kochecoche) and was asked to specify which of the two was a real word. A reliability analysis was used and the alpha coefficient was $\alpha=.81$.

\section{Psycholinguistic Parameters}

Stimuli used in this study were divided as a function of various psycholinguistic parameters: word length (short vs. long), familiarity (low familiarity vs. high familiarity), and syllabic structure (CV vs. CCV). Word length was measured by the number of letters, which is a better predictor than the number of syllables (Just \& Carpenter, 1984). In this study, "long words" were defined as those with seven or more letters and "short words" as those with six letters or less. Familiarity was measured using Juilland and Chang-Rodríguez's (1964) Spanish word-frequency dictionary, with "familiar words" being defined in this study as those with a score equal to, or greater than, 31 and "unfamiliar words" as those with a score less than 13 . We also selected stimuli taking into account the syllabic structure (i.e., CV, CCV). It has been demonstrated that in the Spanish language, children have more difficulty isolating the initial consonant when it belonged to a syllable-initial consonant cluster (Jiménez \& Haro, 1995). The access to phonological units of speech can be mediated by the complexity of syllable structure of the items on which the operations are performed, as has been also demonstrated by various studies carried out across languages in children (Arnqvist, 1992; Schreuder \& van Bon, 1989; Treiman \& Weatherston, 1992). Decoding words with CV syllable structure would thus be easier than decoding words with CCV syllable structure.

\section{Training Procedure}

All the assessment tests were administered by psychologists in random presentation order to avoid any effect of the presentation of the material. Posttest measures were taken one week after treatment was finished. The children were randomly assigned to the experimental and 
control conditions. The experimental groups participated individually in the training sessions for 30-40 minutes per day, five days a week, during language arts time, to insure the equivalent amount of reading instruction time for experimental participants and for matched untrained controls in the same class. The control group followed the standard reading program during language arts that included listening comprehension, spelling, reading aloud, and reading comprehension activities. However, they did not receive any of the spelling-to-sound units in which the experimental participants were involved. There were 15 sessions in all in the TEDIS (Tratamiento Experimental de la Dislexia; in English, Experimental Treatment of Dyslexia) program. A core technical component in the TEDIS remedial program is the "talking" computer, which gives support and feedback through digitized speech. The items were pronounced by a professional speech trainer and recorded on tape in a studio. Each presentation was sequentially highlighted and spoken by the computer, providing simultaneously orthographic and speech feedback in four experimental conditions (i.e., whole-word, phonemes, syllables, and onset-rime segments; see Appendix 2). Children were allowed to request more speech feedback, by clicking with the mouse, for each item, in which case, the item sound was immediately delivered through the headphones. When the subject asked for speech feedback, only the relevant item was presented on the screen. During the computer-based word reading, requests for speech feedback and the number of correctly read words were registered by the computer. The RT of each stimulus was also registered by the computer since the whole word appeared on the screen (after segmentation according to their various conditions) until the participant pronounced it successfully. The examiner decided that a word was correctly read when the participant did not make reading errors such as substitutions, deletions, additions, etc. When the child had three failures with the same word, the examiner would press the keyboard and thus display the presentation of a new word.

In an initial trial session, the children were trained in all of the TEDIS program requirements. Once the treatment sessions started, the examiners were present only to guarantee the optimal technical functioning of the program, to record on tape children's reading, and to ensure that the participants performed the experimental tasks correctly. The total number of words per session was 40 , the total of number of words across the treatment being 600 nouns. All stimuli were grouped in the following way: (a) shorter words with low familiarity and CV syllable structure; (b) shorter words with low familiarity and CCV syllable structure; (c) shorter words with high familiarity and CV syllable structure; (d) shorter words with high familiarity and CCV syllable structure; (e) long words with low familiarity and CV syllable structure; (f) long words with low familiarity and CCV syllable structure; (g) long words and high familiarity and CV syllable structure; and (h) long words and high familiarity and CCV syllable structure. Every eight words, the program asked a multiple-choice comprehension question to ensure that children were paying attention to the task. In this task, children had to indicate with the mouse which of the pictures shown on the screen was related to a target word.

In the experimental conditions, children were asked to read aloud, as accurately and quickly as possible, the 40 words per session that were presented on the center of the screen of the computer (in the case of whole-word condition) and, simultaneously pronounced by a woman's voice. In the three segmented-word conditions, the procedure was the same, but in theses cases, children were asked to pronounce each segment of the word (i.e., phoneme by phoneme, syllable by syllable, and the onset and the rime) that were also pronounced by a woman's voice, and then to read the whole word aloud. They had the option of (a) asking for more speech feedback on the same word (or sub-word units) by clicking with the mouse in order to check that they had read the word correctly, or (b) clicking with the mouse after reading the word to continue with the task. When the subject was able to pronounce the word correctly, he or she pressed the keyboard to obtain the next word.

\section{Results}

\section{Pretest-Posttest Measures}

A $5 \times 2$ Group (Phoneme, Whole Word, Syllable, OnsetRime, Control) $\times$ Training (Pretest, Posttest) multivariate analysis of variance (MANOVA) was performed on each of the different dependent variables: word and pseudoword reading, reading comprehension, phonological awareness, and orthographic-phonological reading tasks. Table 2 contains means and standard deviations for the five groups in each of the pretest-posttest measures.

Word and Pseudoword Reading. The reading results indicated that the main effect of Training was significant, $F(6,65)=92.80, p=.001, \eta^{2}=.90$, but was subsumed under a significant interaction Group $\times$ Training, $F(24$, $227)=1.81, p=.014, \eta^{2}=.14$. In an attempt to test whether there were differences between groups across time, tests of simple main effect confirmed that the pretestposttest gains were greater for the phoneme condition, $F(6$, $67)=2.65, p<.023$, and syllable condition, $F(6,67)=$ $2.39, p<.037$, in comparison to the control group. On the other hand, there were no significant differences between pretest-posttest gains for the onset-rime condition, $F(6$, $67)=2.05, p=.07$, and whole-word condition, $F(6,67)$ $=1.49, p=.19$, in comparison to the control group (see Figure 1). 
Table 2

Means and Standard Deviations of the Pretest and Posttest Measures

\begin{tabular}{|c|c|c|c|c|c|c|c|c|c|c|}
\hline \multicolumn{11}{|c|}{ Training Groups } \\
\hline & \multicolumn{2}{|c|}{$\begin{array}{l}\text { Control } \\
(n=18)\end{array}$} & \multicolumn{2}{|c|}{$\begin{array}{l}\text { Phoneme } \\
(n=15)\end{array}$} & \multicolumn{2}{|c|}{$\begin{array}{l}\text { Whole-Word } \\
\qquad(n=17)\end{array}$} & \multicolumn{2}{|c|}{$\begin{array}{l}\text { Syllable } \\
(n=16)\end{array}$} & \multicolumn{2}{|c|}{$\begin{array}{l}\text { Onset-rime } \\
\quad(n=17)\end{array}$} \\
\hline & $M$ & $S D$ & $M$ & $S D$ & $M$ & $S D$ & $M$ & $S D$ & $M$ & $S D$ \\
\hline \multicolumn{11}{|c|}{ Phonological awareness } \\
\hline Pretest & 6.72 & 1.87 & 7.06 & 1.74 & 6.67 & 1.21 & 7.12 & 1.26 & 7.19 & 1.29 \\
\hline Posttest & 7.67 & 1.68 & 8.53 & 1.29 & 7.91 & 1.08 & 8.48 & 1.11 & 8.74 & 0.87 \\
\hline \multicolumn{11}{|c|}{ Phonological word decoding } \\
\hline Pretest & 23.7 & 7.8 & 24.8 & 5.7 & 23.5 & 7.3 & 24.0 & 6.7 & 27.1 & 4.4 \\
\hline Posttest & 26.5 & 5.4 & 28.4 & 3.9 & 26.4 & 3.4 & 27.5 & 4.6 & 29.7 & 2.7 \\
\hline \multicolumn{11}{|c|}{ Orthographic word decoding } \\
\hline Pretest & 20.4 & 5.5 & 20.6 & 3.9 & 22.5 & 4.9 & 21.1 & 4.2 & 22.8 & 5.1 \\
\hline Posttest & 21.7 & 5.3 & 22.8 & 4.7 & 21.4 & 5.7 & 22.4 & 3.6 & 24.5 & 3.9 \\
\hline \multicolumn{11}{|c|}{ Word-Pseudoword reading } \\
\hline Pretest & 112.8 & 12.8 & 103.6 & 15.2 & 104.8 & 10.5 & 103.9 & 15.1 & 106.6 & 13.2 \\
\hline Posttest & 113.7 & 19.8 & 117.0 & 11.0 & 116.2 & 12.3 & 118.6 & 11.6 & 121.9 & 9.4 \\
\hline \multicolumn{11}{|c|}{ Reading comprehension } \\
\hline Pretest & 2.83 & 1.65 & 2.96 & 1.77 & 2.78 & 1.60 & 3.12 & 1.90 & 3.03 & 3.65 \\
\hline Posttest & 3.56 & 1.77 & 3.26 & 1.74 & 3.26 & 1.92 & 3.81 & 2.14 & 3.65 & 1.99 \\
\hline
\end{tabular}

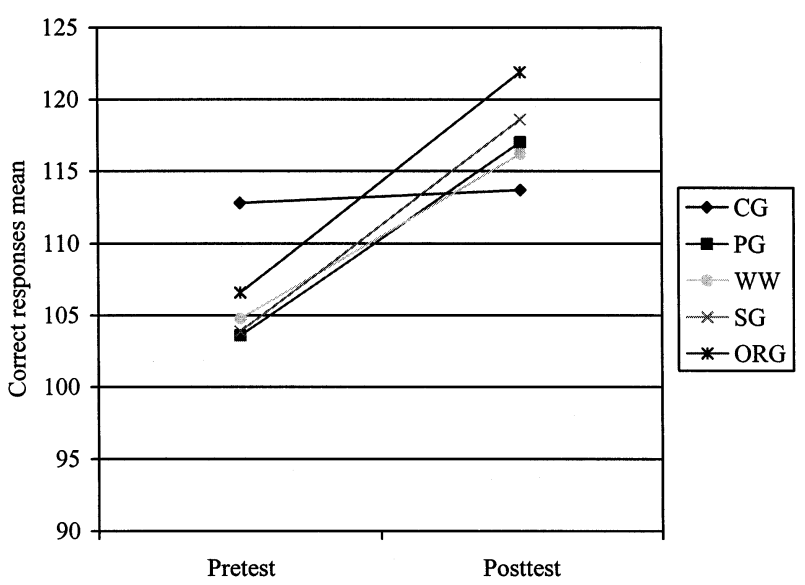

Figure 1. Effect of Group $\times$ Training interaction on word and pseudoword reading

Note: $\mathrm{CG}=$ Control Group; $\mathrm{PG}=$ Phoneme Group; WW = Whole-Word Group; SG = Syllable Group; ORG = Onset-Rime Group.

Phonological Awareness, Orthographic-Phonological Reading Tasks. There were no significant group differences across time in phonological awareness, phonological word decoding and orthographic word decoding tasks $(F<1)$.

Reading Comprehension. The main effect of training was significant, $F(2,72)=16.50, p=.001, \eta^{2}=.31$, indicating that posttest scores were higher in comparison to pretest scores.

\section{Training Session Measures}

Design 1. A $4 \times 2 \times 15$ Group (Phoneme, Whole Word, Syllable, Onset-Rime) $\times$ Word Linguistic Structure $(\mathrm{CV}$ vs. $\mathrm{CCV}) \times$ Training Sessions (1 vs. 15) mixed MANOVA was performed on the number of accurately read words, number of speech feedbacks, and RT.

Reading accuracy. This analysis yielded a main effect of word linguistic structure, $F(1,53)=9.83, p=.003$, MSE $=11.8, \eta^{2}=.16$, and a main effect of training sessions, $F(14,40)=2.09, p=.035, \mathrm{MSE}=11.69, \eta^{2}=.42$. These results indicate that reading accuracy was greater for $\mathrm{CV}$ words than for CCV words, and that reading accuracy varied during computer-based word reading.

Speech feedback. This analysis yielded a main effect of training sessions, $F(14,40)=2.93, p=.004$, MSE $=64.1$, $\eta^{2}=.51$, indicating that the number of helps calls varied during computer-based word reading. Also, a Group $\times$ Word Linguistic Structure interaction was significant, $F(3,53)=$ $3.01, p=.038, \mathrm{MSE}=4.42, \eta^{2}=.15$. These results indicated that speech feedback was greater for CCV words in the onset-rime group in comparison to the syllable group, $F(1,59)=4.07, p=.048, \mathrm{MSE}=42.9$.

Reading time. This analysis yielded a main effect of training sessions, $F(14,40)=6.87, p=.001, \mathrm{MSE}=2813,5$, $\eta^{2}=.67$, indicating that RT varied during computer-based word reading. Also, this analysis yielded a main effect of group, $F(3,61)=6.65, p=.001, \mathrm{MSE}=11521.87, \eta^{2}=$ .25 , but was subsumed under a significant interaction Group $\times$ Word Linguistic Structure, $F(3,61)=5.36, p=.002, \mathrm{MSE}$ 
$=271.5, \eta^{2}=.21$. Test of simple main effect confirmed that RT was greater for CCV words in the phoneme group, $F(1$, $69)=26.3, p=.001, \mathrm{MSE}=1275.4$, and the syllable group, $F(1,69)=3.96, p=.05, \mathrm{MSE}=191.5$.

Design 2. A $4 \times 2 \times 15$ Group (Phoneme, Whole Word, Syllable, Onset-Rime) $\times$ Familiarity (familiar vs. nonfamiliar) $\times$ Training Sessions (1 vs. 15) mixed MANOVA was performed on the number of accurately read words, number of speech feedbacks, and RT.
Reading accuracy. This analysis yielded a main effect of familiarity, $F(1,53)=8.44, p=.005, \mathrm{MSE}=3.03, \eta^{2}=$ .14 , and a main effect of training sessions, $F(13,41)=2.24$, $p=0.025, \mathrm{MSE}=1.89, \eta^{2}=.42$. These results indicate that reading accuracy was greater for familiar words than for unfamiliar words, and that reading accuracy varied during computer-based word reading.

Speech feedback. A Group $\times$ Training Sessions $\times$ Familiarity interaction was significant, $F(39,122)=1.50, p$

Table 3

Means and Standard Deviations of the Amount of Speech Feedback during Training by Group and Linguistic Parameters

Feed-back

Familiar words

Unfamiliar words

\begin{tabular}{|c|c|c|c|c|c|c|c|c|c|c|c|c|c|c|c|c|}
\hline \multirow{2}{*}{$\begin{array}{l}\text { Training } \\
\text { sessions }\end{array}$} & \multicolumn{2}{|c|}{$\begin{array}{c}\text { Phoneme } \\
(n=15)\end{array}$} & \multicolumn{2}{|c|}{$\begin{array}{l}\text { Whole-Word } \\
\quad(n=17)\end{array}$} & \multicolumn{2}{|c|}{$\begin{array}{l}\text { Syllable } \\
(n=16)\end{array}$} & \multicolumn{2}{|c|}{$\begin{array}{l}\text { Onset-rime } \\
\quad(n=17)\end{array}$} & \multicolumn{2}{|c|}{$\begin{array}{r}\text { Phoneme } \\
(n=17)\end{array}$} & \multicolumn{2}{|c|}{$\begin{array}{l}\text { Whole-Word } \\
\qquad(n=17)\end{array}$} & \multicolumn{2}{|c|}{$\begin{array}{l}\text { Syllable } \\
(n=16)\end{array}$} & \multicolumn{2}{|c|}{$\begin{array}{l}\text { Onset-rime } \\
\quad(n=17)\end{array}$} \\
\hline & $M$ & $S D$ & $M$ & $S D$ & $M$ & $S D$ & $M$ & $S D$ & $M$ & $S D$ & $M$ & $S D$ & $M$ & $S D$ & $M$ & $S D$ \\
\hline 1 & 3.57 & 2.93 & 3.94 & 6.34 & 1.93 & 2.13 & 5.81 & 4.05 & 3.00 & 2.60 & 3.29 & 5.53 & 1.50 & 1.56 & 4.88 & 4.27 \\
\hline 2 & 1.93 & 1.71 & 1.35 & 1.77 & 1.13 & 2.00 & 1.94 & 3.75 & 2.07 & 2.19 & 1.41 & 2.40 & 1.75 & 2.27 & 3.00 & 3.72 \\
\hline 3 & 2.80 & 2.68 & 0.82 & 1.47 & 0.81 & 1.42 & 2.53 & 3.48 & 1.40 & 1.80 & 0.94 & 1.68 & 1.56 & 2.16 & 2.65 & 3.44 \\
\hline 4 & 1.07 & 1.91 & 1.71 & 2.39 & 0.50 & 1.32 & 2.12 & 2.96 & 0.80 & 0.86 & 1.24 & 1.15 & 1.06 & 1.18 & 1.71 & 2.85 \\
\hline 5 & 1.13 & 2.07 & 0.94 & 1.53 & 0.63 & 0.96 & 1.59 & 2.18 & 1.33 & 2.29 & 1.00 & 1.58 & 1.19 & 1.22 & 2.41 & 2.53 \\
\hline 6 & 1.27 & 2.49 & 0.88 & 2.03 & 0.56 & 1.03 & 1.35 & 2.21 & 1.20 & 1.37 & 0.69 & 0.95 & 1.31 & 2.33 & 1.53 & 2.15 \\
\hline 7 & 0.87 & 1.77 & 0.47 & 0.87 & 0.63 & 0.62 & 0.71 & 1.31 & 1.20 & 1.78 & 0.94 & 1.30 & 1.06 & 2.26 & 1.24 & 1.44 \\
\hline 8 & 0.60 & 0.83 & 0.71 & 1.16 & 0.88 & 1.09 & 1.00 & 1.46 & 0.93 & 1.39 & 0.53 & 1.07 & 0.25 & 0.45 & 0.47 & 1.28 \\
\hline 9 & 0.87 & 1.06 & 0.65 & 1.27 & 0.38 & 0.81 & 1.59 & 3.06 & 0.40 & 0.83 & 0.88 & 1.11 & 0.81 & 1.05 & 1.12 & 1.27 \\
\hline 10 & 0.60 & 0.74 & 0.29 & 0.47 & 0.19 & 0.40 & 0.65 & 1.06 & 0.47 & 0.74 & 0.59 & 1.06 & 0.56 & 0.73 & 0.88 & 1.41 \\
\hline 11 & 0.64 & 1.28 & 0.88 & 1.32 & 0.69 & 1.14 & 1.00 & 1.46 & 0.67 & 0.98 & 0.75 & 0.77 & 0.88 & 1.31 & 0.71 & 1.21 \\
\hline 12 & 0.57 & 0.94 & 0.59 & 1.28 & 1.06 & 1.18 & 0.76 & 0.83 & 0.21 & 0.80 & 0.94 & 1.20 & 0.50 & 1.26 & 1.00 & 1.66 \\
\hline 13 & 0.21 & 0.58 & 0.65 & 0.79 & 0.38 & 0.81 & 1.12 & 1.58 & 0.43 & 0.85 & 0.59 & 1.06 & 0.63 & 1.15 & 0.94 & 1.64 \\
\hline 14 & 0.43 & 0.65 & 0.29 & 0.77 & 0.69 & 1.20 & 0.31 & 0.48 & 0.36 & 0.74 & 1.47 & 1.55 & 0.88 & 1.71 & 1.12 & 1.69 \\
\hline 15 & 0.83 & 1.70 & 0.45 & 0.89 & 0.28 & 0.46 & 0.72 & 0.89 & 0.21 & 0.43 & 0.76 & 1.09 & 1.19 & 1.28 & 0.88 & 1.15 \\
\hline & & & & $\mathrm{Sh}$ & & & & & & & & & Tos & & & \\
\hline
\end{tabular}

\begin{tabular}{|c|c|c|c|c|c|c|c|c|c|c|c|c|c|c|c|c|}
\hline \multirow{2}{*}{$\begin{array}{l}\text { Training } \\
\text { sessions }\end{array}$} & \multicolumn{2}{|c|}{$\begin{array}{l}\text { Phoneme } \\
(n=15)\end{array}$} & \multicolumn{2}{|c|}{$\begin{array}{l}\text { Whole-Word } \\
\qquad(n=17)\end{array}$} & \multicolumn{2}{|c|}{$\begin{array}{l}\text { Syllable } \\
(n=16)\end{array}$} & \multicolumn{2}{|c|}{$\begin{array}{l}\text { Onset-rime } \\
\quad(n=17)\end{array}$} & \multicolumn{2}{|c|}{$\begin{array}{l}\text { Phoneme } \\
(n=15)\end{array}$} & \multicolumn{2}{|c|}{$\begin{array}{l}\text { Whole-Word } \\
\qquad(n=17)\end{array}$} & \multicolumn{2}{|c|}{$\begin{array}{l}\text { Syllable } \\
(n=16)\end{array}$} & \multicolumn{2}{|c|}{$\begin{array}{l}\text { Onset-rime } \\
\quad(n=17)\end{array}$} \\
\hline & $M$ & $S D$ & $M$ & $S D$ & $M$ & $S D$ & $M$ & $S D$ & $M$ & $S D$ & $M$ & $S D$ & $M$ & $S D$ & $M$ & $S D$ \\
\hline 1 & 3.14 & 2.03 & 3.18 & 6.25 & 1.50 & 1.74 & 4.88 & 4.33 & 3.43 & 2.98 & 4.06 & 5.79 & 1.93 & 2.16 & 5.81 & 4.02 \\
\hline 2 & 1.73 & 1.67 & 1.24 & 2.02 & 1.25 & 1.69 & 1.65 & 2.74 & 2.27 & 2.55 & 1.53 & 2.32 & 1.63 & 2.83 & 3.29 & 4.58 \\
\hline 3 & 2.40 & 2.75 & 0.88 & 1.45 & 1.19 & 1.60 & 2.76 & 3.58 & 1.80 & 1.86 & 0.88 & 1.58 & 1.19 & 2.07 & 2.41 & 3.74 \\
\hline 4 & 0.80 & 1.15 & 1.24 & 1.48 & 0.56 & 1.09 & 1.88 & 2.80 & 1.07 & 1.49 & 1.71 & 1.96 & 1.00 & 1.26 & 1.94 & 2.84 \\
\hline 5 & 1.07 & 2.34 & 0.71 & 1.05 & 1.31 & 2.24 & 1.24 & 1.52 & 1.47 & 2.26 & 0.94 & 1.30 & 1.13 & 1.82 & 2.71 & 3.31 \\
\hline 6 & 1.33 & 1.76 & 1.06 & 1.53 & 1.19 & 1.76 & 1.18 & 1.55 & 1.00 & 1.73 & 0.56 & 1.03 & 0.75 & 1.13 & 1.94 & 2.59 \\
\hline 7 & 1.07 & 2.22 & 0.88 & 1.45 & 0.75 & 1.61 & 0.88 & 1.41 & 1.40 & 2.06 & 0.94 & 1.52 & 0.88 & 1.78 & 1.71 & 2.17 \\
\hline 8 & 0.87 & 1.85 & 0.59 & 1.06 & 0.50 & 0.73 & 0.35 & 0.79 & 0.93 & 1.39 & 0.41 & 0.87 & 0.38 & 0.50 & 0.82 & 1.70 \\
\hline 9 & 0.27 & 0.59 & 0.82 & 1.51 & 0.31 & 0.60 & 0.65 & 1.22 & 0.73 & 0.80 & 0.76 & 0.75 & 1.38 & 1.59 & 1.47 & 1.33 \\
\hline 10 & 0.67 & 1.35 & 0.59 & 1.28 & 0.56 & 0.81 & 1.41 & 2.37 & 0.67 & 0.90 & 0.65 & 0.93 & 0.38 & 0.62 & 1.06 & 1.82 \\
\hline 11 & 0.60 & 0.91 & 0.38 & 0.81 & 0.38 & 0.81 & 0.41 & 0.71 & 0.67 & 1.05 & 0.65 & 0.79 & 0.69 & 0.95 & 0.94 & 1.30 \\
\hline 12 & 0.71 & 1.49 & 1.00 & 1.58 & 0.50 & 1.51 & 0.94 & 1.34 & 0.14 & 0.53 & 0.82 & 1.13 & 0.69 & 0.95 & 1.06 & 1.48 \\
\hline 13 & 0.71 & 1.14 & 0.71 & 1.57 & 0.38 & 0.50 & 0.94 & 1.20 & 0.29 & 0.83 & 0.47 & 0.87 & 1.31 & 1.74 & 0.76 & 1.15 \\
\hline 14 & 0.29 & 0.61 & 0.29 & 0.59 & 0.31 & 0.60 & 0.82 & 1.19 & 0.29 & 0.73 & 1.82 & 2.07 & 0.94 & 1.88 & 1.41 & 1.66 \\
\hline 15 & 0.21 & 0.58 & 0.41 & 0.80 & 0.44 & 0.89 & 0.25 & 0.58 & 0.43 & 0.51 & 0.65 & 0.93 & 1.44 & 1.26 & 0.94 & 0.93 \\
\hline
\end{tabular}




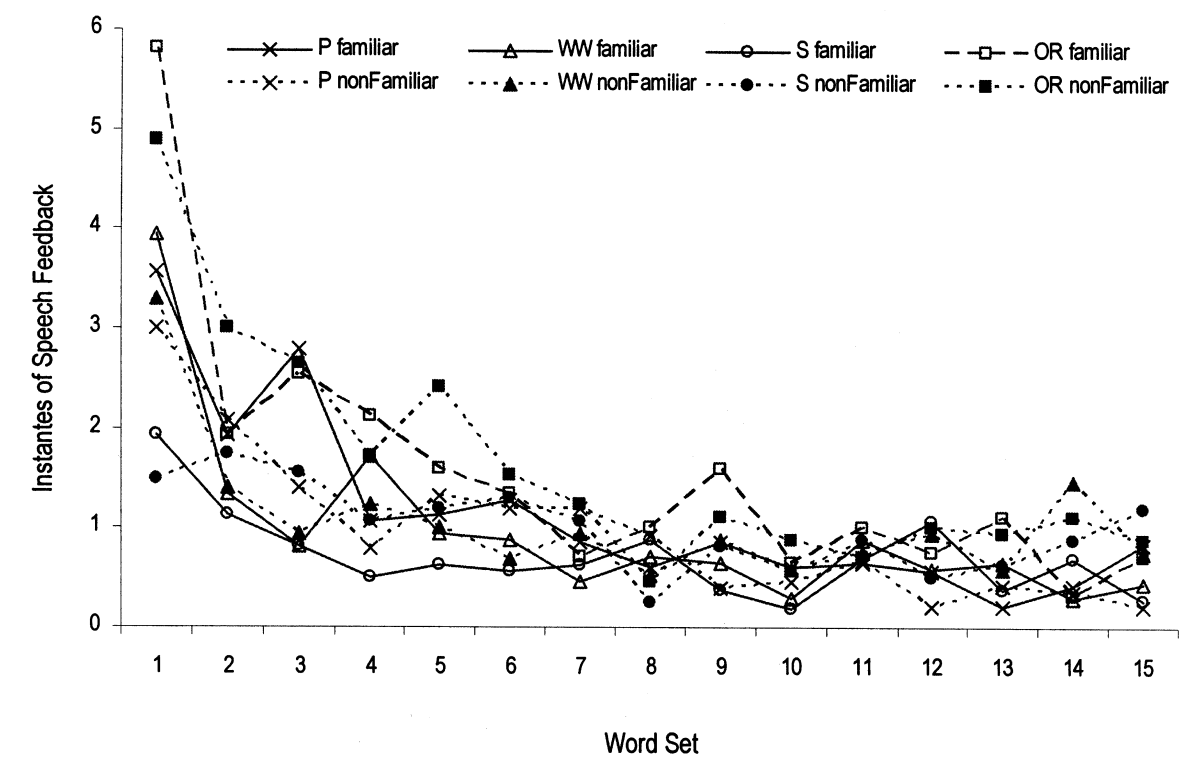

Figure 2. Effect of Group $\times$ Training Sessions $\times$ Familiarity interaction on speech feedback

Note: $\mathrm{P}=$ Phoneme; WW = Whole-Word; $\mathrm{S}=$ Syllable; $\mathrm{OR}=$ Onset-Rime.

Note: $\mathrm{CG}=$ Control Group; $\mathrm{PG}=$ Phoneme Group; WW = Whole-Word Group; SG = Syllable Group; ORG = Onset-Rime Group.

$=.049, \mathrm{MSE}=1.22, \eta^{2}=.32$. Subsequent test of simple main effect revealed that speech feedback was greater for the phoneme group in unfamiliar words in comparison to whole word group during computer-based word reading, $F(14,40)$ $=2.38, p=.016, \mathrm{MSE}=1.90, \eta^{2}=.46$. Table 3 displays means and standard deviations for amounts of speech feedback during training by group and familiarity (see Figure 2).

Reading time. A Group $\times$ Familiarity interaction was significant, $F(3,61)=8.60, p=.001, \mathrm{MSE}=152.69, \eta^{2}=.30$.
A subsequent test of simple main effect revealed that RT was greater for unfamiliar words in the phoneme group, $F(1,61)=$ $44.03, p=.001, \mathrm{MSE}=782.06, \eta^{2}=.42$, and onset-rime group, $F(1,61)=10.43, p=.002, \mathrm{MSE}=185.25, \eta^{2}=.15$.

Design 3. A $(4 \times 2 \times 15)$ Group (Phoneme, Whole Word, Syllable, Onset-Rime) $\times$ Word Length (short vs. long) $\times$ Training Sessions (1 vs. 15) mixed MANOVA was performed on the number of accurately read words, number of instances of speech feedback, and RT.

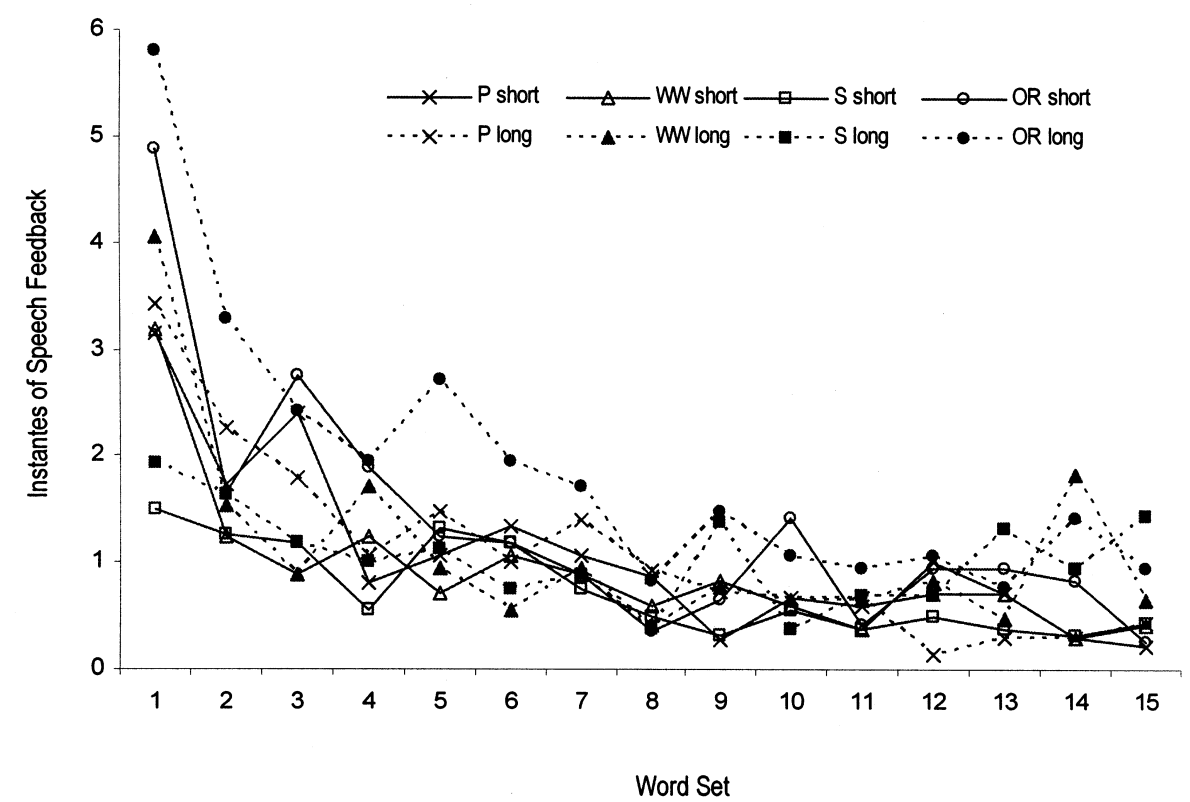

Figure 3. Effect of Group $\times$ Training Sessions $\times$ Word Length interaction on speech feedback Note: $\mathrm{P}=$ Phoneme; WW = Whole-Word; $\mathrm{S}=$ Syllable; $\mathrm{OR}=$ Onset-Rime. 
Reading accuracy. There was a main effect of word length, $F(1,53)=18.2, p=.001, \operatorname{MSE}=12.3, \eta^{2}=.25$, but was subsumed under a significant Length $\times$ Group interaction, $F(3,53)=4.46, p=.007, \mathrm{MSE}=3.03, \eta^{2}=$ .20. The subsequent test of simple main effect revealed that reading accuracy was greater for long words in the onsetrime group in comparison to syllable group, $F(1,53)=4.60$, $p=.037, \mathrm{MSE}=12.80, \eta^{2}=.08$. Also, there was main effect of training sessions, $F(14,40)=2.09, p=.035$, MSE $=1.69, \eta^{2}=.42$, indicating that reading accuracy varied during computer-based reading.

Speech feedback. A Group $\times$ Training Sessions $\times$ Word Length interaction was significant, $F(42,119)=1.53, p=$ $.038, \mathrm{MSE}=1.40, \eta^{2}=.35$. The subsequent test of simple

Table 4

Means and Standard Deviations for Reading Time (ms) during Training by Group and Word Length

\begin{tabular}{|c|c|c|c|c|c|c|c|c|c|c|c|c|c|c|c|c|}
\hline \multirow{4}{*}{$\begin{array}{l}\text { Training } \\
\text { sessions }\end{array}$} & \multicolumn{14}{|c|}{ Feed-back } & & \\
\hline & \multicolumn{8}{|c|}{ Short words } & \multicolumn{8}{|c|}{ Long words } \\
\hline & \multicolumn{2}{|c|}{$\begin{array}{c}\text { Phoneme } \\
(n=15)\end{array}$} & \multicolumn{2}{|c|}{$\begin{array}{l}\text { Whole-Word } \\
\qquad(n=17)\end{array}$} & \multicolumn{2}{|c|}{$\begin{array}{l}\text { Syllable } \\
(n=16)\end{array}$} & \multicolumn{2}{|c|}{$\begin{array}{l}\text { Onset-rime } \\
\quad(n=17)\end{array}$} & \multicolumn{2}{|c|}{$\begin{array}{l}\text { Phoneme } \\
(n=15)\end{array}$} & \multicolumn{2}{|c|}{$\begin{array}{l}\text { Whole-Word } \\
\qquad(n=17)\end{array}$} & \multicolumn{2}{|c|}{$\begin{array}{l}\text { Syllable } \\
(n=16)\end{array}$} & \multicolumn{2}{|c|}{$\begin{array}{l}\text { Onset-rime } \\
\quad(n=17)\end{array}$} \\
\hline & $M$ & $S D$ & $M$ & $S D$ & $M$ & $S D$ & $M$ & $S D$ & $M$ & $S D$ & $M$ & $S D$ & $M$ & $S D$ & $M$ & $S D$ \\
\hline 1 & 2833 & 1326 & 2986 & 1444 & 2296 & 669 & 2848 & 1886 & 3561 & 1644 & 3544 & 1928 & 2324 & 707 & 3325 & 2016 \\
\hline 2 & 2417 & 1036 & 2396 & 1207 & 1669 & 777 & 2272 & 1378 & 3421 & 2454 & 2611 & 1389 & 1677 & 812 & 2881 & 1874 \\
\hline 3 & 2329 & 1289 & 1862 & 1054 & 1816 & 837 & 2258 & 1803 & 3093 & 2183 & 2261 & 1135 & 1646 & 706 & 2462 & 2117 \\
\hline 4 & 2311 & 1003 & 1833 & 1086 & 1426 & 856 & 2130 & 1541 & 2561 & 1383 & 1983 & 1301 & 1395 & 888 & 2389 & 2315 \\
\hline 5 & 2201 & 1282 & 1667 & 862 & 1387 & 729 & 2124 & 1511 & 2557 & 1759 & 1688 & 949 & 1410 & 730 & 2442 & 2045 \\
\hline 6 & 2088 & 1458 & 1743 & 979 & 1330 & 719 & 1671 & 1125 & 2423 & 2137 & 1834 & 907 & 1323 & 683 & 2179 & 1837 \\
\hline 7 & 2474 & 2967 & 1240 & 832 & 1363 & 970 & 1610 & 1088 & 2849 & 3082 & 1361 & 823 & 1455 & 935 & 1551 & 1040 \\
\hline 8 & 2280 & 1384 & 1434 & 797 & 1324 & 820 & 1311 & 667 & 2642 & 1969 & 1592 & 963 & 1310 & 917 & 1423 & 875 \\
\hline 9 & 2028 & 1336 & 1437 & 666 & 1257 & 629 & 1564 & 787 & 2212 & 1359 & 1471 & 755 & 1435 & 884 & 1959 & 1312 \\
\hline 10 & 1705 & 1017 & 1212 & 639 & 1065 & 576 & 1432 & 872 & 2034 & 1207 & 1389 & 833 & 1334 & 1263 & 1720 & 1321 \\
\hline 11 & 2112 & 1412 & 1049 & 712 & 932 & 660 & 1274 & 873 & 1929 & 1210 & 1015 & 635 & 892 & 393 & 1291 & 886 \\
\hline 12 & 1602 & 1455 & 950 & 803 & 976 & 852 & 1245 & 848 & 1690 & 1240 & 955 & 747 & 980 & 701 & 1252 & 963 \\
\hline 13 & 1868 & 1231 & 1390 & 839 & 996 & 620 & 1566 & 1110 & 2041 & 1397 & 1291 & 675 & 1065 & 707 & 1761 & 1404 \\
\hline 14 & 1762 & 1077 & 1192 & 699 & 959 & 685 & 1424 & 1059 & 2238 & 1379 & 1227 & 646 & 1002 & 637 & 1601 & 1406 \\
\hline 15 & 2048 & 1222 & 1095 & 585 & 1070 & 630 & 1304 & 940 & 2361 & 1757 & 1049 & 515 & 1275 & 793 & 1665 & 1264 \\
\hline
\end{tabular}

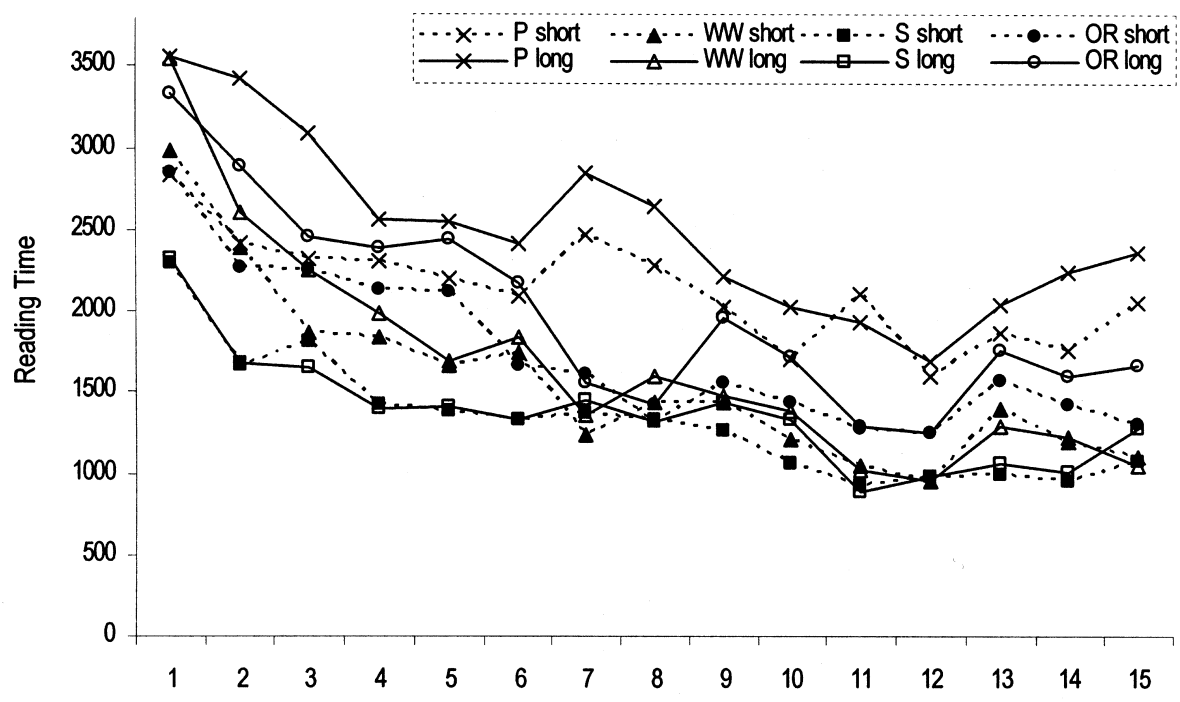

Word Set

Figure 4. Effect of Group $\times$ Training Sessions $\times$ Word Length interaction on reading time Note: $\mathrm{P}=$ Phoneme; WW = Whole-Word; $\mathrm{S}=$ Syllable; $\mathrm{OR}=$ Onset-Rime. 
main effect revealed that speech feedback was greater for long words in the syllable group, $F(15,39)=2.29, p=.019$, $\mathrm{MSE}=2.16, \eta^{2}=.47$, and the onset-rime group, $F(15,39)$ $=2.01, p=.041$, MSE $=2.16, \eta^{2}=.44$. Table 3 contains means and standard deviations for reading time during training by group and word length (see Figure 3).

Reading time. A Group $\times$ Training Sessions $\times$ Word Length interaction was significant, $F(42,143)=1.71, p=$ $.011, \mathrm{MSE}=29.64, \eta^{2}=.33$. The subsequent test of simple main effect revealed that RT was greater for long words in the phoneme group during computer-based reading, $F(15$ $, 47)=6.62, p=.001, \mathrm{MSE}=267.5, \eta^{2}=.68$. Table 4 contains means and standard deviations for reading time during training by group and word length (see Figure 4).

\section{Discussion}

The aim of this study was to assess the effects of different spelling-to-sound units (whole word, phoneme, syllable, onset-rime) on computer speech-based reading for the remediation of children with reading disabilities in a transparent orthography. Data provide a controlled experimental demonstration that the deficient word recognition skills of children with $\mathrm{RD}$ are amenable to remediation, and that their phonological decoding performance can be improved by manipulating different units in the instructional program. The results indicated that there was an improvement in the phoneme and syllable conditions in phonological decoding (word and pseudoword reading). However, we did not find transfer effects of computer-assisted practice on word recognition to reading comprehension. This finding is in line with research showing that the generalization of isolated-word intervention to reading comprehension is limited (see Swanson, 1999, for a review).

The improvements in the phoneme group in word decoding support the idea that the phonemic level plays an important role in dyslexia in a consistent orthography such as that of Spanish. By forcing attention to individual letters within the word, and with the speech feedback simultaneously provided during training, this could provide the basis for promoting appreciation of grapheme-phoneme correspondences, an ability that is not achieved by children with severe reading deficiencies.

It was also found that the syllable condition contributed to improving phonological decoding. Spanish is a language with consistent grapheme-phoneme correspondences: syllables are well defined, pronunciation depends on syllabic context, and syllable boundaries are always clear. It is empirically demonstrated that syllables are computed during the processing of Spanish printed words in adults (Álvarez, et al., 1998; Carreiras, et al., 1993; Dominguez, et al., 1993). In addition, Jiménez and Guzmán (2003), using a sample of Spanish children from first and second grade, found that the effect of positional syllable frequency (PSF) (i.e., the number of times that a syllable appears in a particular position in a word) does emerge in the second grade, when the child has acquired the alphabetic principle. This means that Spanish children use the syllable unit in word reading at an early age and, in view of the results obtained in the present study, older reading disabled children seem to continue doing this despite the fact that they do not succeed in rendering the phonological reading procedure automatic. In fact, Jiménez and Rodrigo (1994) suggested that the lack of interaction found between PSF and reading level implies that the failure of the group with RD lay in the procedure of letter-by-letter grapheme-phoneme conversion, not syllable-by-syllable. Thus, the route of syllable-by-syllable phonological assembly was not slower in the RD group. Consequently, in the case of the dyslexics who have not acquired the necessary automatization of the graphemephoneme correspondences, the syllable level would be an adequate level for remediation.

In relation to the whole-word condition, it was found that this unit did not contribute to improving phonological decoding. A possible explanation for this finding has to do with the fact that, although the dual route model of reading is functional in Spanish despite its orthographic transparency (Defior, et al., 1996; Valle-Arroyo, 1989), only the good readers would use the orthographic route to read in an effective way. There is empirical evidence in Spanish in favor of the hypothesis that RD children have a bias for lexical over phonological reading procedures. This would appear to be a compensatory strategy to make up for their deficits in phonological decoding, because they produced more visual and morphological errors (Jiménez \& Hernández-Valle, 2000; Rodrigo \& Jiménez, 1999). Thus, the whole-word condition does not seem to be an effective way to remediate a phonological processing deficit, and this is, in fact, the core problem for RD children. The wholeword condition is not directed toward the deficits in phonological decoding of printed words because, in that case, the reader does not have to attend to the word's component elements and, thus, might not learn phonological reading strategies. In fact, there is evidence that in naming words under conditions that require extensive phonological computation, Spanish children who learn to read by a meaning-oriented approach have more difficulties than children who learn by a code-oriented approach (Jiménez \& Guzmán, 2003). Another possible explanation for this finding has to do with the hypothesis that the whole-word condition may be helpful for learning just a limited set of words, but less than optimal for stimulating more generalized reading skills.

The onset-rime condition was not as effective as the phoneme and syllable conditions on phonological decoding. This finding is not surprising because this type of unit does not seem to be as relevant in a language where there is a direct correspondence between graphemes and phonemes, and where the syllable boundaries are well defined. The 
observation of this result is congruous with the finding of Jiménez, Álvarez et al., (2000), who focused on the effects of (sub-syllabic) intrasyllabic units on lexical decision performance in normal readers and children with $\mathrm{RD}$ in a transparent orthography. They found that neither Spanish normal readers nor children with RD seem to use mappings that involve intrasyllabic units in lexical access, relying instead more on the phonemic level. Thus, they suggested that, in a transparent orthography such as Spanish, remedial education may be more successful if it concentrates on the phoneme level rather than on onset-rime units, in contrast to what has been suggested by Treiman (1992) in the English language. In fact, a finding in the present study that supports the above-mentioned idea is that the onset-rime group began with the highest rate of requests of speech feedback among the four groups.

Taking into account the results of the training measures (reading accuracy, speech feedback, and RT), it was found that phonological requirements in a transparent orthography such as Spanish show their effects during computer-based word reading when children asked for more speech feedback under conditions that required extensive phonological computation (e.g., low frequency words and long words). Thus, the phoneme condition children requested more speech feedback in comparison with the whole-word condition when words were of low frequency. Likewise, syllable and onsetrime condition children asked for a greater number of instances of speech feedback when words were long, though a greater number of instances of speech feedback for CCV words was requested by onset-rime group. These results also indicate that, in the learning process, children with $\mathrm{RD}$ were selective when requesting speech feedback, as the frequency of requests was significantly related to familiarity, word length, and syllabic structure. These data are also coincident with those found by Van Daal and Reitsma (1993), where children with RD were more selective in requesting speech feedback because they better discriminated hard-to-read words from easy-to-read words. In addition, phonological requirements are evident in the result concerning the measure of RT. In fact, RT was greater for long words and unfamiliar words in the phoneme group during computer-based reading, and also greater for CCV words in the phoneme and syllable conditions. Unexpectedly, RT was greater in onset-rime condition when words were unfamiliar, and there was more accuracy for long words in comparison with the syllable condition.

In sum, in this study, participants were able to ask for the spoken form of the word whenever they wished, and the results indicated that reading on the computer with speech feedback significantly improved phonological decoding of RD children, especially when the instruction involved the phonemic level and the syllable level. However, these positive results must be tempered because of the lack of improvements in other measures such as reading comprehension or phonological awareness. It is conceivable that effective training for severely disabled readers may require a longer period than the present 15 sessions for transfer effects to become observable. Some authors suggested that an optimal period of treatment could be of 40 hours (Torgesen et al., 2001; Wise, Ring, \& Olson, 1999). However, in our experimental study, children only received approximately between 10 and 15 hours of training. Moreover, another limitation was that the standardized reading test used for assessment was a small corpus of words. Likewise, a well constructed experimental test sampling across different categories as a function of psycholinguistic parameters (i.e., familiarity, length, ...) would provide a better measure of remedial results. Clearly, future research should attempt to clarify these issues.

Despite the above limitations, the research findings demonstrate that reading by the computer with speech feedback may constitute a helpful remedial tool for Spanish children with reading disabilities, especially in the teaching of orthographic units such as syllables and phonemes.

\section{References}

Álvarez, C.J., de Vega, M., \& Carreiras, M. (1998). La sílaba como unidad de activación léxica en la lectura de palabras trisílabas. Psicothema, 10, 371-386.

Arnqvist, A. (1992). The impact of consonant clusters on preschool children's phonemic awareness: A comparison between readers and nonreaders. Scandinavian Journal of Psychology, 33, 29-35.

Bowey, J.A., \& Francis, J. (1991). Phonological analysis as a function of age and exposure to reading instruction. Applied Psycholinguistics, 12, 91-121.

Carreiras, M., Álvarez, C., \& de Vega, M. (1993). Syllable frequency and visual word recognition in Spanish. Journal of Memory and Language, 32, 766-780.

Cattell, R.B., \& Cattell, A.K.S. (1950/1960). Culture fair intelligence test, scale 1. Champaign, IL: Institute for Personality and Ability Testing. (Spanish translation: Cordero, De la Cruz, \& Seisdedos, Tests de Factor "g”. Escala 1. Madrid: T.E.A., Ediciones, 1989).

Cuetos, F., Rodríguez, B., \& Ruano, E, (1996). Batería de evaluación de los procesos lectores de los niños de Educación Primaria (PROLEC). Madrid, Spain: T.E.A., Ediciones.

Daneman, M.M., \& Carpenter, P.A. (1980). Individual differences in working memory and reading. Journal of Verbal Learning and Verbal Behavior, 19, 450-466.

Defior, S., Justicia, F., \& Martos, F. (1996). The influence of lexical and sublexical variables in normal and poor Spanish readers. Reading and Writing: An interdisciplinary Journal, 8, 487-497.

Domínguez, A., \& Cuetos, F. (1992). Desarrollo de las habilidades de reconocimiento de palabras en niños con distinta competencia lectora. Cognitiva, 2, 193-208.

Domínguez, A., Cuetos, F., \& de Vega, M. (1993). Efectos diferenciales de la frecuencia silábica posicional: dependencia del tipo de prueba y características de los estímulos. Estudios de Psicología, 50, 5-31. 
García-Albea, J., Sánchez, R., \& del Viso, S. (1982). Efectos de la frecuencia de uso en el reconocimiento de palabras. Investigación Psicológica, 1, 24-63.

Jiménez, J.E. (1997). A reading-level design study of phonemic processes underlying reading disabilities in a transparent orthography. Reading and Writing: An Interdisciplinary Journal, 9, 23-40.

Jiménez, J.E., Álvarez, C., Estévez, A., \& Hernández-Valle, I. (2000). Onset-rime units in visual word recognition in Spanish normal readers and children with reading disabilities. Learning Disabilities Research \& Practice, 15, 135-141.

Jiménez, J.E., García, E., Ortiz, M.R., Hernández-Valle, I., Guzmán, R., Rodrigo, M., Estévez, A., Díaz, A., \& Hernández, S. (2005). Is the deficit in phonological awareness better explained in terms of task differences or effects of syllable structure? Applied Psycholinguistics, 26, 267-283.

Jiménez, J.E., \& Guzmán, R. (2003). The influence of code-oriented versus meaning-oriented approaches to reading instruction on word recognition in the Spanish language. International Journal of Psychology, 38, 65-78.

Jiménez, J.E., \& Haro, C. (1995). Effects of word linguistic properties on phonological awareness in Spanish children. Journal of Educational Psychology, 87, 193-201.

Jiménez, J.E., \& Hernández-Valle, I. (2000). Word identification and reading disorders in the Spanish language. Journal of Learning Disabilities, 32, 267-275.

Jiménez, J. E., \& Ramírez, G. (2002). Identifying subtypes of reading disabilities in the Spanish language. The Spanish Journal of Psychology, 5, 3-19.

Jiménez, J.E., \& Rodrigo, M. (1994). Is it true that the differences in reading performance between students with and without LD cannot be explained by IQ? Journal of Learning Disabilities, 27, 155-163.

Jones, K.M., Torgesen, J.K., \& Sexton, M.A. (1987). Using computer guided practice to increase decoding fluency in learning disabled children: A study using the Hint and Hunt Program. Journal of Learning Disabilities, 20, 122-128.

Juilland, A., \& Chang-Rodríguez, E. (1964). Frequency dictionary of Spanish words. Holland: Mouton.

Just, M.A., \& Carpenter, P.A. (1984). Using eye fixation to study reading conmprehension. In D.E. Kieras \& M.A. Just (Eds.), New methods in reading comprehension research (pp. 151182). Hillsdale, NJ: Erlbaum.

Liberman, I.Y., Liberman, A.M., Mattingly, I.G., \& Shankweiler, D. (1980). Orthography and the beginning reader. In J. Kavanagh \& R. Venezky (Eds.), Orthograhpy, reading and dyslexia (pp. 137-153). Baltimore: University Park Press.

Lovett, M.W., Barron, R.W., Forbes, J.E., Cuksts, B., \& Steinbach, K.A. (1994). Computer speech-based training of literacy skills in neurologically impaired children: A controlled evaluation. Brain and Language, 47, 117-154.

Lundberg, I. (1995). The computer as a tool of remediation in the education of students with reading disabilities: A theory-based approach. Learning Disability Quarterly, 18, 89-99.
Olofsson, A. (1992). Synthetic speech and computer aided reading for reading disabled children. Reading \& Writing: An Interdisciplinary Journal, 4, 165-178.

Olson, R. K., Foltz, G., \& Wise, B. (1986). Reading instruction and remediation with the aid of computer speech. Behavior Research Methods, Instruments, \& Computers, 18, 93-99.

Olson, R.K., Kliegl, R., Davidson, B.J., \& Foltz, G. (1985). Individual and developmental differences in reading disability. In G.E. MacKinnon \& T.G. Waller (Eds.), Reading research: Advances in theory and practice, (Vol. 4, pp. 1-64). New York: Academic Press.

Olson, R. K., \& Wise, B. (1992). Reading on the computer with orthographic and speech feedback: An overview of the Colorado remediation project. Reading \& Writing: An interdisciplinary Journal, 4, 107-144.

Olson, R.K., Wise, B., Conners, F., Rack, J., \& Fulker, D. (1989). Specific deficits in component reading and language skills: Genetic and environmental influences. Journal of Learning Disabilities, 22, 339-348.

Perfetti, C.A. (1985). Reading ability. New York. Oxford University Press.

Rack, J.P., Snowling, M.J., \& Olson, R.K. (1992). The nonword reading deficit in developmental dyslexia: A review. Reading Research Quarterly, 27, 29-53.

Rodrigo, M., \& Jiménez, J.E. (1999). An analysis of the word naming errors of normal readers and reading disabled children in Spanish. Journal of Research in Reading, 22, 180-197.

Rodrigo, M., Jiménez, J.E., García, E., Díaz, A., Ortiz, M.R., Guzmán, R., Hernández-Valle, I., Estévez, A., \& Hernández, S. (2004). Assessment of orthographical processing in Spanish children with dyslexia: The role of lexical and sublexical units. Electronic Journal of Research in Educational Psychology, 2, 105-126.

Schreuder, R., \& van Bon, W. (1989). Phonemic analysis: Effects of word properties. Journal of Research in Reading, 12, 5978.

Siegel, L.S. (1992). An evaluation of the discrepancy definition of dyslexia. Journal of Learning Disabilities, 25, 618-629.

Siegel, L.S., \& Ryan, E.B. (1988). Development of grammaticalsensitivity, phonological, and short term memory skills in normally achieving and subtypes of learning disabled children. Developmental Psychology, 24, 28-37.

Siegel, L.S., \& Ryan, E.B.(1989). The development of working memory in normally achieving and subtypes of learning disabled children. Child Development, 60, 973-980.

Stanovich, K.E. (1988). Explaining the differences between the dyslexic and garden variety poor reader: The phonologicalcore variance-difference model. Journal of Learning Disabilities, 21, 590-612.

Stanovich, K.E., \& Siegel, L.S. (1994). Phenotypic performance profile of children with reading disabilities: A regression-based test of the phonological-core variable-difference model. Journal of Educational Psychology, 86, 24-53.

Swanson, H.L. (1999). Reading research for students with LD: A meta-analysis of intervention outcomes. Journal of Learning Disabilities, 32, 504-532. 
Torgesen, J.K., Alexander, A.W., Wagner, R.K., Rashotte, C.A., Voeller, K., Conway, T., \& Rose, E. (2001). Intensive remedial instruction for children with severe reading disabilities: Immediate and long-term outcomes from two instructional approaches. Journal of Learning Disabilities, 34, 33-59.

Torgesen, J.K., \& Barker, T.A. (1995). Computers as aids in the prevention and remediation of reading disabilities. Learning Disability Quarterly, 18, 76-87.

Treiman, R. (1992). The role of intrasyllabic units in learning to read and spell. In P.B. Gough, L. Ehri, \& R. Treiman (Eds.), Reading acquisition (pp. 65-106). Hillsdale, NJ: Erlbaum.

Treiman, R., \& Weatherston, S. (1992). Effects of linguistic structure on children's ability to isolate initial consonants. Journal of Educational Psychology, 84, 174-181.

Valle-Arroyo, F. (1989). Errores de lectura y escritura. Un modelo dual. Cognitiva, 2, 35-63.

Van Daal, V.H.P., \& Reitsma, P. (1993). The use of speech feedback by normal and disabled readers in computer-based reading practice. Reading and Writing: An Interdisciplinary Journal, 5, 243-259.

Van den Bos, K.P., \& Spelberg, H.C.L. (1994). Word identification routes and reading disorders. In K.P. Van den Bos, L.S. Siegel, D.J. Bakker, \& D.L. Share (Eds.), Current directions in dyslexia research (pp. 201-219). Lisse, Netherlands: Swets \& Zeitlinger.
Van den Bosch, A., Content, A., Daelemans, W., \& de Gelder, B. (1994). Measuring the complexity of writing systems. Journal of Quantitative Linguistics, 1, 178-188.

Van der Leij, A., (1994). Effects of computer-assisted instruction on word and pseudoword reading of reading-disabled student. In K.P. Van den Bos, L.S. Siegel, D.J. Bakker, \& D.L. Share (Eds.), Current directions in dyslexia research (pp. 251-267). Lisse, Netherlands: Swets \& Zeitlinger.

Wagner, R.K., \& Torgesen, J.K., (1987). The nature of phonological processing and its causal role in the acquisition of reading skills. Psychological Bulletin, 101, 192-212.

Wise, B., Olson, R., Anstett, M., Andrews, L., Terjak, M., Schneider, V., \& Kostuch, J. (1989). Implementing a longterm computerized remedial reading program with synthetic speech feedback: Hardware, software, and real-world issues. Behaviour Research Methods, Instruments, and Computers, 21, 173-180.

Wise, B.W., Ring, J., \& Olson, R. (1999). Training phonological awareness with and without explicit attention to articulation. Journal of Experimental Child Psychology, 72, 271-304.

Received June, 1, 2006 Review received October, 15, 2006 Accepted October 20, 2006 


\section{Appendix 1}

\section{Stimuli used in the Phonological Awareness Tasks (English trasnlation in brackets)}

\section{Odd-word-out task}

1. sol (sun) silla (chair) saco (bag) libro (book)

2. reloj (watch) ratón (mouse) tanque (tank) rueda (wheel)

3. mano (hand) camisa (shirt) mono (monkey) mesa (table)

4. tambor (drum) tijeras (scissors) tortuga (tortoise) rana (frog)

5. barco (ship) tenedor (fork) bota (boot) bicicleta (bicycle)

6. llave (key) coche (car) caracol (snail) cuchillo (knife)

7. fuego (fire) foca (seal) maleta (suitcase) falda (skirt)

8. pino (pine) pato (duck) perro (dog) campana (bell)

9. dado (die) pipa (pipe) dedo (finger) ducha (shower)

10. jirafa (giraffe) jaula (cage) pies (foot) jersey (sweater)

\section{Phoneme segmentation task}

1. baño (bathroom)

2. faro (lighthouse)

3. dado (die)

4. jarra (pitcher)

5. gato (cat)

6. sapo (frog)

7. pala (shovel)

8. malo (bad)

9. casa (house)

10. rata (rat)

11. tapa (lid)

12. fila (row)

13. bebe (drink)

14. jugo (juice)
Phoneme reversal test

1. goma (eraser)

2. mesa (table)

3. pico (beak)

4. roto (broken)

5. coche (car)

6. foca (seal)

7. tiza (chalk)

8. jefe (boss)

9. boca (mouth)

10. silla (chair)

11. dedo (finger)

12. mono (monkey)

13. gota (drop)

14. remo (oar) 


\section{Appendix 2}

Stimuli used in the Phonological Awareness Tasks (English trasnlation in brackets)

Phoneme condition

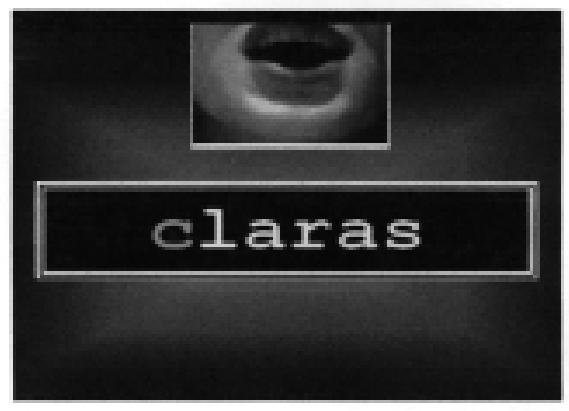

Syllable condition

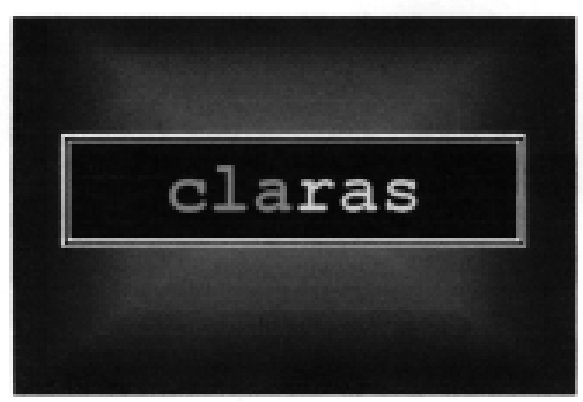

Onset-rime condition

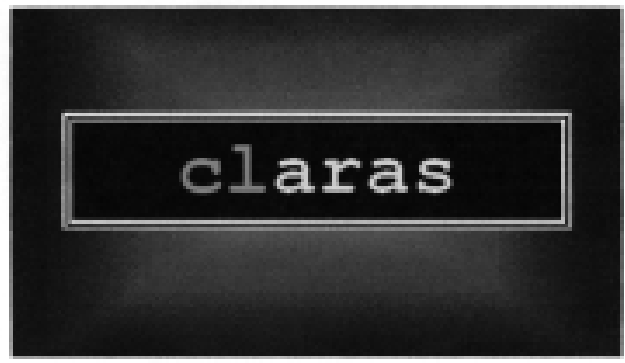

Whole-Word condition

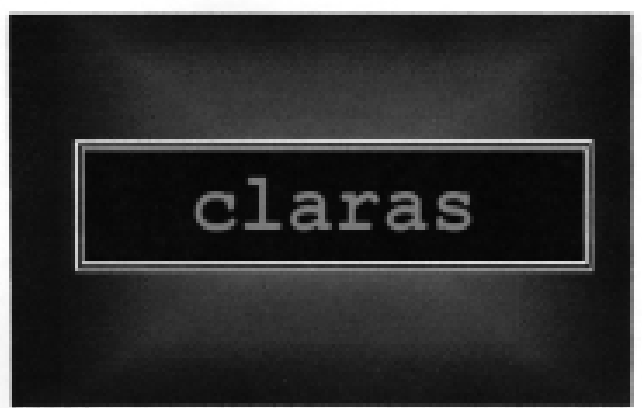

